\title{
EFEKTIVITAS PLANT GROWTH PROMOTING RHIZOBACTERIA Pseudomonas fluorescens DALAM PENGENDALIAN HAYATI PENYAKIT BULAI PADA TANAMAN JAGUNG
}

\section{The Effectivity of Plant Growth Promoting Rhizobacteria of Pseudomonas fluorescens through Biological Control on Downy Mildew in Maize}

\author{
Hatyanta Nuha Pradhipta, Irianti Kurniasari*, Ugik Romadi \\ Program Studi Penyuluhan Pertanian, Sekolah Tinggi Penyuluhan Pertanian Malang \\ Jl. Dr.Cipto 144 A Lawang-Malang 65200 \\ *Alamat Korespondensi: kurnia_saree@yahoo.com
}

\begin{abstract}
ABSTRAK
Bulai merupakan penyakit utama pada tanaman jagung yang disebabkan jamur patogen Peronosclerospora maydis. P. Maydis menyebabkan potensi kehilangan hasil. Berbagai pengendalian yang dilakukan belum memberikan hasil yang optimal dan bahkan menimbulkan dampak negatif terhadap lingkungan dan kesehatan manusia. Rizobakteria pemicu pertumbuhan tanaman Pseudomonas fluorescens diketahui berpotensi sebagai pengendali penyakit bulai yang ramah lingkungan. Penelitian ini bertujuan untuk mengetahui efektivitas $P$. Fluorescens terhadap penekanan penyakit bulai dan pertumbuhan pada tanaman jagung. Penelitian ini menggunakan Rancangan Acak Kelompok dengan konsentrasi larutan P. Fluorescens sebagai perlakuan terdiri dari: $0 \mathrm{ml} / \mathrm{L}, 50 \mathrm{ml} / \mathrm{L}, 75 \mathrm{ml} / \mathrm{L}, 100 \mathrm{ml} / \mathrm{L}$ dan fungisida fenamidon $50 \%$. Parameter yang diamati pada penelitian ini meliputi tinggi tanaman, jumlah daun, kejadian penyakit dan intensitas penyakit bulai. Hasil penelitian menunjukan bahwa $P$. Fluorescens dapat efektif mengendalikan penyakit bulai pada tanaman jagung.
\end{abstract}

Kata kunci: penyakit bulai, Rhizobakteria pemicu pertumbuhan tanaman, Pseudomonas fluorescens, jagung.

\begin{abstract}
Downy mildew is the main disease in maize that caused by the fungus pathogen Peronosclerospora maydis. $P$. maydis and its significantly effect to yield loss. The various controls have been done without the optimum result instead had inverse effect on human health. Plant Growth Promoting Rhizobacteria Pseudomonas fluorescens can be used as biological control agents against downy mildew and environmental friendly. Objective of this study was to know the effectiveness of P. fluorescens to control downey mildew and growth characters in maize. Randomized Block Design were applied with concentration of P. fluorescens as a treatment consist of $0 \mathrm{ml} / \mathrm{L}, 50$ $\mathrm{ml} / \mathrm{L}, 75 \mathrm{ml} / \mathrm{L}, 100 \mathrm{ml} / \mathrm{L}$, and fenamidone fungicide $50 \%$ as treatment check. Observed variables were plant height, number of leaf and symptom and intensity of downy mildew. The results showed that P. fluorescens effective to control downy mildew in maize.
\end{abstract}

Keywords: downy mildew, Plant Growth Promoting Rhizobacteria, Pseudomonas fluorescens, maize

\section{PENDAHULUAN}

Jagung (Zea mays L.) merupakan salah satu komoditas pangan yang strategis di Indonesia. Pada sektor pangan komoditas jagung merupakan sumber karbohidrat kedua setelah beras, sedangkan pada sektor peternakan $51 \%$ bahan pakan pabrikan berasal dari jagung. Dari tahun ketahun permintaan jagung terus meningkat seiring dengan perkembangan dan peningkatan dalam bidang pangan dan usaha peternakan. Menurut Pusdatin Kementerian Pertanian tahun 2016, setiap tahun terjadi peningkatan kebutuhan jagung untuk bahan pangan sebesar 1,02\% dan bahan baku industri pakan sebesar 3,33\%. Berdasarkan hal tersebut, peningkatan kebutuhan jagung harus diikuti oleh peningkatan produksi 
jagung, sehingga kebutuhan secara nasional dapat tercukupi oleh produksi jagung dari dalam negeri.

Salah satu kendala dalam upaya peningkatan produksi jagung di sektor onfarm adalah adanya penyakit bulai. Penyakit bulai merupakan penyakit utama pada tanaman jagung yang disebabkan oleh jamur patogen Peronosclerospora maydis dengan potensi kehilangan hasil mencapai $100 \%$ (Wakman, 2004). Jamur patogen ini menginfeksi tanaman jagung pada umur 23 minggu (Semangun, 2004). Ciri umum yang ditimbulkan dari serangan bulai adalah munculnya butiran putih pada daun yang merupakan spora jamur patogen. Masa kritis tanaman jagung terserang bulai berlangsung sejak benih ditanam hingga usia 35 hari.

Menurut Badan Litbang Pertanian Tahun 2012, penyakit bulai dapat dikendalikan secara fisika dan kimia. Pengendalian secara fisika dengan menggunakan varietas toleran, pergiliran tanaman, sanitasi lingkungan, dan eradikasi tanaman, sedangkan pengendalian secara kimia menggunakan fungisida. Pengendalian secara fisika memiliki beberapa kelemahan diantaranya yaitu mahalnya benih varietas toleran dan juga tidak spesifik lokasi, sedangkan pergiliran tanaman dan sanitasi lingkungan kurang efektif dilakukan dikarenakan cuaca yang berubah-ubah dan kurangnya dukungan petani sekitar. Pengendalian secara kimiawi dapat menyebabkan resistensi patogen $P$. maydis, pencemaran air, tanah, udara dan hasil pertanian, yang pada akhirnya menimbulkan gangguan kesehatan manusia (Burhanuddin, 2009). Berdasarkan hal tersebut, maka perlu dicari alternatif pengendalian lain yang lebih ramah lingkungan, yaitu dengan pengendalian hayati.

Salah satu pengendalian hayati yang sedang dikembangkan yaitu menggunakan Plant Growth Promoting Rhizobacteria (PGPR). PGPR adalah bakteri pengkoloni akar yang berfungsi sebagai biofertilizer, biostimulan dan bioprotektan yang dapat memberikan efek menguntungkan terhadap tanaman (Rai, 2006). Penelitian ini bertujuan untuk mengetahui efektivitas PGPR Pseudomonas fluorescens terhadap pengendalian penyakit bulai pada tanaman jagung.

\section{METODE PENELITIAN}

Penelitian ini dilaksanakan pada bulan Januari sampai Maret 2018 di Laboratorium Bioteknologi Sekolah Tinggi Penyuluhan Pertanian Malang dan lahan petani di Kecamatan Ngantru Kabupaten Tulungagung. Bahan yang dipakai dalam penenelitian ini yaitu benih jagung varietas Pioner 27 (P-27), biakan cair PGPR Pseudomonas fluorescens, fungisida berbahan aktif fenamidon, aquades, alkohol 
70\%, pupuk ZA, pupuk NPK (15:15:15), pupuk kandang, daun jagung bergejala bulai, dan gula.

Penelitian menggunakan Rancangan Acak Kelompok dengan 5 perlakuan, yaitu P1 (0/Kontrol Negatif), P2 (P. fluorescens 50 ml/L), P3 (P. fluoresce 75 ml/L), P4 (P. Fluoresce $100 \mathrm{ml} / \mathrm{L}$ ) dan P5 (Fungisida fenamidon $50 \%$ ) Setiap perlakuan terdiri dari 5 kali ulangan, sehingga diperoleh 25 kombinasi perlakuan, dan masing-masing perlakuan terdiri dari 3 sampel tanaman.

\section{Perbanyakan Isolat $\boldsymbol{P}$. fluorescens}

Isolat murni $P$. fluorescens yang digunakan merupakan koleksi dari UPT Proteksi TPH Dinas Pertanian Provinsi Jawa Timur. P. fluorescens diperbanyak menggunakan ekstrak kedelai dan gula, kemudian dilakukan fermentasi secara aerob pada suhu ruangan menggunakan alat fermentor sederhana. Penghitungan populasi isolat $P$. fluorescens menggunakan alat haemocytometer dan didapatkan populasi $3,2 \times 10^{9} \mathrm{cfu} / \mathrm{mL}$..

\section{Pelapisan Benih (Seed Coating)}

Benih jagung yang akan dilapisi, dicuci menggunakan air bersih untuk menghilangkan fungisida yang menempel pada benih. Pelapisan benih menggunakan biakan cair $P$. fluorencens, dilakukan dengan merendam benih sesuai konsentrasi setiap perlakuan selama 8 jam. Pelapisan benih menggunakan fungisida berbahan aktif fenamidon 50\% selama 5 menit. Benih kemudian dikeringkan dengan cara dianginanginkan (Oktaviani, 2013).

\section{Penyiapan Lahan}

$\begin{array}{llllll}\text { Lahan } & \text { berukuran } & 7 & \mathrm{x} & 10 & \mathrm{~m}\end{array}$ dibersihkan dari gulma, kemudian dicangkul. Lahan dibuat menjadi bedengan dengan ukuran $1,6 \times 1 \mathrm{~m}$ dan tinggi bedengan $20 \mathrm{~cm}$. Jarak antar bedengan yaitu $30 \mathrm{~cm}$.

\section{Penanaman Jagung}

Penanaman jagung menggunakan jarak tanam 25x70 cm dengan jumlah benih setiap lubang tanam yaitu 1 biji. Setiap lubang tanam ditutup menggunakan pupuk kandang dengan dosis $50 \mathrm{~g} / \mathrm{lubang}$ tanam.

\section{Inokulasi Jamur Patogen P. maydis}

Daun jagung yang bergejala penyakit bulai dicacah, kemudian direndam ke dalam larutan gula 5\% selama 4 jam. Inokulasi $P$. maydis dilakukan dengan cara menyemprotkan air rendaman tersebut pada titik tumbuh tanaman jagung sebanyak 1 mL. Inokulasi dilakukan sebelum matahari terbit pada saat tanaman jagung berumur 10 7 HST (Hari Setelah Tanam) (Zainuddin et al., 2014).

\section{Penyemprotan $P$. fluorescens}

Penyemprotan tanaman dilakukan pada saat umur tanaman jagung 7 HST. Penyemprotan dilakukan pada seluruh bagian tanaman menggunakan $P$. fluorescens dengan konsentrasi $50 \mathrm{~mL} / \mathrm{L}$, sedangkan kontrol negatif dan positif 
p-ISSN: 1410-0029; e-ISSN2549-6786

Agrin Vol. 23, No. 1, April 2019

disemprot menggunakan aquades

(Oktaviani, 2013).

Parameter Pengamatan

Kategori penyakit yang digunakan seperti di bawah ini (Ginting, 2013).

Parameter yang diamati pada Skala Kategori Penyakit penelitian ini meliputi tinggi tanaman, jumlah daun, kejadian penyakit dan intensitas penyakit bulai. Tinggi tanaman diamati mulai dari permukaan tanah hingga ujung daun. Jumlah daun dihitung berdasarkan jumlah daun yang telah mekar sempurna. Pengamatan tinggi tanaman dan jumlah daun dilakukan pada umur 1-5 Minggu Setelah Tanam (MST).

Pengamatan kejadian penyakit bulai dilakukan setiap minggu mulai umur 2 sampai 5 MST, menggunakan rumus Zainuddin et al., (2014):

$$
K P=\frac{n}{v} \times 100 \%
$$

Keterangan:

$K P:$ Kejadian penyakit (\%)

$n$ : Jumlah tanaman sakit

$v$ : Jumlah tanaman yang diamati

Intensitas penyakit diamati setiap minggu mulai umur 2 sampai 5 MST menggunakan rumus:

$$
I S=\frac{\sum(n \times v)}{N \times Z} \times 100 \%
$$

Keterangan:

IS : Intensitas penyakit (\%)

$n$ : Jumlah daun sakit pada setiap kategori penyakit

$v$ : Nilai skala dari setiap kategori penyakit

$N$ : Jumlah daun yang diamati

$Z$ : Skala tertinggi dari kategori penyakit

\section{HASIL DAN PEMBAHASAN}

\section{Tinggi Tanaman}

Hasil analisis statistik menunjukkan bahwa penggunaan PGPR P. fluorescens memberikan pengaruh yang berbeda nyata pada tinggi tanaman dibandingkan tanpa perlakuan pada umur 1 hingga 5 MST, tetapi tidak menunjukkan beda nyata antar perlakuan konsentrasi larutan $P$. fluorescens yang diaplikasikan (Tabel 1). Hal tersebut sesuai dengan hasil penelitian Khalimi dan Wirya (2009), bahwa terdapat perbedaan yang nyata antara benih yang diberi perlakuan $P G P R$ dengan benih tanpa perlakuan. Gholami et al., (2009), melaporkan bahwa aplikasi PGPR pada perkecambahan benih jagung mampu menaikkan tinggi tanaman jagung secara 
signifikan. Dalam proses kolonisasi akar, PGPR mampu memproduksi hormon pertumbuhan seperti auksin, sitokinin, dan giberelin (Gupta et al., 2015). IAA merupakan bentuk aktif dari auksin yang berfungsi meningkatkan pertumbuhan tanaman melalui peningkatan penyerapan unsur N, P, K, Ca, dan Mg (Sivasakthi et al., 2014). Sitokinin berfungsi dalam pembelahan sel, sedangkan giberelin berfungsi mendiferensiasi sel tumbuhan (Rahni, 2012; Noumavo et al., 2013). Penambahan hormon pertumbuhan yang dihasilkan PGPR inilah yang bertanggungjawab terhadap proses pertumbuhan vegetatif yaitu peningkatan tinggi tanaman jagung.

\section{Jumlah Daun}

Hasil analisis statistik menunjukkan bahwa penggunaan PGPR P. fluorescens memberikan pengaruh yang berbeda nyata terhadap jumlah daun setiap tanaman dibandingkan konsentrasi $0 \mathrm{ml}$ pada umur 1 hingga 5 MST, tetapi tidak memberikan pengaruh yang berbeda nyata antar perlakuan konsentasi larutan $P$. fluorescens yang diaplikasikan sebagaimana tertera pada Tabel 2. Mekanisme PGPR dalam peningkatan pertumbuhan tanaman adalah sebagai penghasil fitohormon. Pada dasarnya, setiap tanaman memiliki hormon pertumbuhan dalam jumlah tertentu. Melalui introduksi PGPR terjadi penambahan sitokinin dan giberelin secara eksogen, sehingga terjadi peningkatan kandungan sitokinin dan giberelin dalam tanaman. Proses ini akan meningkatkan jumlah sel dan ukuran sel yang bersamasama dengan hasil fotosintesis yang tinggi di awal penanaman sehingga secara tidak langsung akan mempercepat pertumbuhan vegetatif tanaman (Dewi, 2008). Jatniaka et al. (2013) menyatakan P. fluorescens mampu meningkatkan tinggi tananaman, diameter batang dan jumlah daun tanaman jagung. Hal yang sama juga dilaporkan oleh Noumavo et al. (2013), aplikasi Pseudomonas fluorescens dalam perkecambahan benih jagung mampu meningkatkan jumlah daun dan luas daunyang signifikan dibandingkan dengan kontrol.

Tabel 1. Tinggi tanaman pada berbagai umur dan perlakuan

\begin{tabular}{lrrrrr}
\hline \multirow{2}{*}{ Perlakuan } & \multicolumn{5}{c}{ Umur tanaman } \\
\cline { 2 - 6 } & $1 \mathrm{MST}$ & $2 \mathrm{MST}$ & 3 MST & $4 \mathrm{MST}$ & $5 \mathrm{MST}$ \\
\hline Kontrol & $7,46 \mathrm{a}$ & $25,44 \mathrm{ab}$ & $49,04 \mathrm{a}$ & $81,70 \mathrm{a}$ & $124,14 \mathrm{a}$ \\
$P$. fluorescens $50 \mathrm{ml} / \mathrm{L}$ & $10,20 \mathrm{~b}$ & $32,34 \mathrm{~b}$ & $61,62 \mathrm{~b}$ & $100,42 \mathrm{c}$ & $140,64 \mathrm{abc}$ \\
$P$. fluoresce $75 \mathrm{ml} / \mathrm{L}$ & $11,18 \mathrm{~b}$ & $33,26 \mathrm{~b}$ & $61,40 \mathrm{~b}$ & $103,40 \mathrm{c}$ & $151,56 \mathrm{c}$ \\
$P$. fluoresce $100 \mathrm{ml} / \mathrm{L}$ & $11,12 \mathrm{~b}$ & $33,50 \mathrm{~b}$ & $61,32 \mathrm{~b}$ & $95,44 \mathrm{bc}$ & $143,04 \mathrm{bc}$ \\
Fungisida fenamidon 50\% & $8,80 \mathrm{ab}$ & $22,56 \mathrm{a}$ & $48,86 \mathrm{a}$ & $87,58 \mathrm{ab}$ & $129,38 \mathrm{ab}$ \\
\hline
\end{tabular}

Keterangan: Angka pada kolom sama yang diikuti huruf yang sama menunjukan tidak berbeda nyata pada Uji DMRT $p=0,05$. 
Tabel 2. Jumlah daun per tanaman pada berbagai umur dan perlakuan

\begin{tabular}{lllllc}
\hline \multirow{2}{*}{ Perlakuan } & \multicolumn{5}{c}{ Umur tanaman } \\
\cline { 2 - 6 } & 1 MST & $2 \mathrm{MST}$ & 3 MST & $4 \mathrm{MST}$ & $5 \mathrm{MST}$ \\
\hline Kontrol & $2,28 \mathrm{ab}$ & $2,94 \mathrm{a}$ & $4,94 \mathrm{a}$ & $6,80 \mathrm{a}$ & $8,76 \mathrm{a}$ \\
P. fluorescens $50 \mathrm{ml} / \mathrm{L}$ & $2,60 \mathrm{ab}$ & $3,46 \mathrm{ab}$ & $5,94 \mathrm{c}$ & $8,10 \mathrm{~b}$ & $10,00 \mathrm{ab}$ \\
P. fluoresce $75 \mathrm{ml} / \mathrm{L}$ & $2,72 \mathrm{ab}$ & $3,60 \mathrm{ab}$ & $5,66 \mathrm{abc}$ & $7,86 \mathrm{~b}$ & $10,50 \mathrm{~b}$ \\
$P$. fluoresce $100 \mathrm{ml} / \mathrm{L}$ & $2,88 \mathrm{~b}$ & $3,70 \mathrm{~b}$ & $5,74 \mathrm{bc}$ & $7,94 \mathrm{~b}$ & $10,08 \mathrm{ab}$ \\
Fungisida fenamidon $50 \%$ & $2,20 \mathrm{a}$ & $3,26 \mathrm{ab}$ & $5,16 \mathrm{ab}$ & $7,28 \mathrm{ab}$ & $8,94 \mathrm{a}$ \\
\hline
\end{tabular}

Keterangan: Angka pada kolom sama yang diikuti huruf yang sama menunjukan tidak berbeda nyata pada Uji DMRT $p=0,05$.

Tabel 3. Kejadian penyakit bulai pada berbagai umur tanaman dan perlakuan

\begin{tabular}{lcccr}
\hline \multirow{2}{*}{ Perlakuan } & \multicolumn{4}{c}{ Umur tanaman } \\
\cline { 2 - 5 } & $2 \mathrm{MST}$ & 3 MST & $4 \mathrm{MST}$ & 5 MST \\
\hline Kontrol & 0,00 & 6,23 & 6,23 & $34,19 \mathrm{~b}$ \\
$P$. fluorescens $50 \mathrm{ml} / \mathrm{L}$ & 0,00 & 0,00 & 0,00 & $0,00 \mathrm{a}$ \\
$P$. fluoresce $75 \mathrm{ml} / \mathrm{L}$ & 0,00 & 0,00 & 0,00 & $0,00 \mathrm{a}$ \\
$P$. fluoresce $100 \mathrm{ml} / \mathrm{L}$ & 0,00 & 0,00 & 0,00 & $0,00 \mathrm{a}$ \\
Fungisida fenamidon 50\% & 0,00 & 0,00 & 0,00 & $0,00 \mathrm{a}$ \\
\hline
\end{tabular}

Keterangan: Data yang dianalisis statistik ditransformasi dengan transformasi square root $($ SQRT $x+1)$. Angka pada kolom sama yang diikuti huruf yang sama menunjukan tidak berbeda nyata pada Uji $D M R T p=0,05$.

Tabel 4. Intensitas penyakit pada berbagai umur tanaman dan perlakuan

\begin{tabular}{lcccr}
\hline \multirow{2}{*}{ Perlakuan } & \multicolumn{4}{c}{ Umur tanaman } \\
\cline { 2 - 5 } & 2 MST & 3 MST & 4 MST & 5 MST \\
\hline Kontrol & 0,00 & 4,41 & 4,41 & $16,96 \mathrm{~b}$ \\
$P$. fluorescens $50 \mathrm{ml} / \mathrm{L}$ & 0,00 & 0,00 & 0,00 & $0,00 \mathrm{a}$ \\
P. fluoresce $75 \mathrm{ml} / \mathrm{L}$ & 0,00 & 0,00 & 0,00 & $0,00 \mathrm{a}$ \\
$P$. fluoresce $100 \mathrm{ml} / \mathrm{L}$ & 0,00 & 0,00 & 0,00 & $0,00 \mathrm{a}$ \\
Fungisida fenamidon 50\% & 0,00 & 0,00 & 0,00 & $0,00 \mathrm{a}$ \\
\hline
\end{tabular}

Keterangan: Data yang dianalis statistik ditransformasi dengan transformasi square root $(\mathrm{SQRT} x+1)$. Angka pada kolom sama yang diikuti huruf yang sama menunjukan tidak berbeda nyata pada Uji $D M R T p=0,05$.

\section{Kejadian Penyakit}

Pengamatan yang dilakukan mulai minggu kedua sampai minggu kelima MST menunjukkan bahwa aplikasi PGPR Pseudomonas fluorescens dapat menekan kejadian penyakit bulai. Hasil analisis statistik menunjukan bahwa perlakuan PGPR dan fungisida fenamidon pada umur 2-4 MST, dapat mencegah munculnya gejala penyakit bulai, sedangkan pada umur
5 MST, perlakuan tersebut memberikan pengaruh yang berbeda nyata dibandingkan kontrol sebagaimana tertera pada Tabel 3. Mekanisme penekanan PGPR terhadap penyakit telah banyak dilaporkan dalam berbagai penelitian. Jatniaka et al. (2013), melaporkan bahwa Pseudomonas sp. dapat menekan penyakit bulai dengan cara menekan sporulasi jamur patogen Peronosclerospora maydis. Pseudomonas 
fluorescens juga mampu memproduksi antibiotik anti jamur yang berfungsi menghambat pertumbuhan jamur patogen dan enzim ekstraseluler yang berfungsi mendegradasi sel jamur (Sivasakthi et al, 2014). Mekanisme lain juga dilaporkan oleh Gupta et al. (2015), bahwa Pseudomonas sp. mampu memproduksi senyawa siderofor. Seperti diketahui bahwa ion $\mathrm{Fe}$ (besi) merupakan unsur esensial yang dibutuhkan semua mikroorganisme, dengan adanya senyawa siderofor ini, ion $\mathrm{Fe}$ tersebut menjadi tidak tersedia bagi mikroorganisme lain khususnya jamur patogen. Berdasarkan hal tersebut, mekanisme penekanan tunggal ataupun kombinasi yang ditunjukkan $P G P R$ pada akhirnya akan menyebabkan tanaman lebih tahan terhadap penyakit. Hal ini yang menyebabkan tanaman dengan perlakuan $P G P R$ tidak menunjukan gejala penyakit bulai.

Perbedaan yang tidak signifikan antar konsentrasi PGPR yang diaplikasikan diduga disebabkan oleh faktor biotik dan abiotik yang mempengaruhi dalam tahapan pengkolonian pada permukaan akar (Sivasakthi et al, 2014). Jumlah $P$. fluorencens yang diaplikasikan tinggi, tidak menjamin bahwa pengkolonian pada perakaran juga tinggi. Berhasil tidaknya tahapan pengkolonian pada perakaran ini akan mempengaruhi daya hambat antagonis terhadap patogen. Kemunculan gejala penyakit bulai pada tanaman yang diberikan perlakuan fungisida fenamidon juga berhasil ditekan. Hal ini didukung oleh hasil penelitian Korlina dan Amir (2015), yang menyatakan bahwa persentase kemunculan penyakit bulai pada tanaman jagung berfungisida fenamidon lebih rendah dibandingkan penggunaan bahan aktif kimiawi yang lain.

\section{Intensitas Penyakit}

Pengamatan yang dilakukan mulai minggu ketiga sampai minggu kelima setelah tanam menunjukkan bahwa aplikasi PGPR P. fluorencens dapat menekan intensitas penyakit bulai. Hasil analisis statistik menunjukkan bahwa terjadi peningkatan intensitas penyakit pada minggu ketiga sampai kelima setelah tanam pada tanaman tanpa perlakuan (Tabel 4). Tanaman tanpa perlakuan menjadi lebih rentan dibandingkan tanaman berperlakuan PGPR. Pada tanaman yang rentan, proses perkembangan patogen berlangsung lebih baik. Peningkatan intensitas penyakit diduga karena penambahan pupuk kimia secara intensif sebelum tanaman berumur 35 HST. Menurut Surtikanti (2011), bahwa tanaman jagung dengan pemberian pupuk kimia lebih banyak akan mendapatkan serangan jamur penyebab penyakit bulai lebih tinggi. Selain itu, peningkatan intensitas serangan juga diduga karena kondisi lingkungan yang lembap saat musim penghujan sehingga mendorong 
tanaman mengeluarkan air gutasi. Air gutasi ini sangat berperan penting dalam meningkatkan perkecambahan spora jamur penyebab penyakit bulai pada tanaman jagung (Semangun dan Sumardi, 1971).

\section{KESIMPULAN}

Konsentrasi PGPR P. fluorescens 50 $\mathrm{ml} / \mathrm{L}$ paling efisien dalam menekan penyakit bulai dan meningkatkan pertumbuhan tanaman jagung.

\section{DAFTAR PUSTAKA}

Burhanuddin. 2009. Fungisida Metalaksil Tidak Efektif Menekan Penyakit Bulai (Peronosclerospora sp.) di Kalimantan Barat dan Alternatif Pengendaliannya. Prosiding Seminar Serealia. Maros: 395 - 399

Dewi, I.R. 2008. Peranan dan fungsi fitohormon bagi pertumbuhan tanaman. Skripsi. Universitas Padjajaran. Bandung

Ginting, C. 2013. Ilmu Penyakit Tumbuhan Konsep dan Aplikasi. Lembaga Penelitian Universitas Lampung. Lampung

Gholami, A., S. Shahsavani, dan S. Nezarat. 2009. The effect of plant growth promoting rhizobacteria (PGPR) on germination, seedling growth and yield of maize. International Journal of Biological, Biomolecular, Agricultural, Food and Biotechnological Engineering, 3(1): 9 -14 .

Gupta, G., S.S. Parihar, N.K. Ahirwar, S.K. Snehi,danP. Singh, 2015. Plant Growth Promoting Rhizobacteria (PGPR): Current and future prospects for development of sustainable agriculture. Journal Microbial
Biochemical Technology, 7(2): 96 102.

Jatniaka, W., A.L. Abadi dan L.Q. Aini. 2013. Pengaruh aplikasi Bacillus sp. dan Pseudomonas sp. terhadap perkembangan penyakit bulai yang disebabkan oleh jamur patogen Peronosclerospora maydis pada tanaman jagung. Jurnal HPT Universitas Brawijaya, (1): 19 - 29.

Khalimi, K. dan G. Wirya. 2009. Pemanfaatan plant growth promoting rhizobakteria untuk biostimulan dan bioprotektan. Ecotrophic, (4): 131 135.

Korlina, A. dan A.M. Amir. 2015. Efektivitas Jenis Fungisida Terhadap Penyakit Bulai (Peronosclerospora maydis) Pada Jagung. Prosiding Seminar Serealia. Malang.

Noumavo, P.A., E. Kochoni,Y.O. Didagbé, Adjanohoun, A., Allagbé, M., Sikirou, R., Gachomo, E.W., Kotchoni, S.O., Baba-Moussa, L. 2013. Effect of different plant growth promoting rhizobacteria on maize seed germination and seedling development. American Journal of Plant Sciences, 4: 1013 - 1021 .

Oktaviani, A.R. 2013. Keefektifan beberapa isolat plant growth promoting rhizobacteria untuk menekan penyakit bulai (Peronosclerospora maydis (Rac.) Shaw) pada tanaman jagung manis. Skripsi. Fakultas Pertanian. Institut Pertanian Bogor. Bogor.

Rai, M.K. 2006. Hand Book of Microbial Biofertilizers. Food Products Press, An Imprint of the Haworth Press, Inc. New York.

Rahni, N.M. 2012. Efek fitohormon PGPR terhadap pertumbuhan tanaman jagung (Zea mays). Jurnal Agribisnis dan Pengembangan Wilayah, 3(2): 27 -35 . 
Semangun, H. 2004. Penyakit-Penyakit Tanaman Pangan Di Indonesia. Gadjah Mada University Press. Yogyakarta.

Semangun, H., dan Sumardi. 1971. The influence of guttation water of maize seedling on Sclerospora maydis. Proc. Workshop VII Inter-Asian Corn Prog., Los Bonos: $101-104$.

Sivasakthi, S., Usharani, G., dan Saranraj, P. 2014. Biocontrol potentiality of Plant Growth Promoting Bacteria (PGPR)-Pseudomonas fluoroscens and Bacillus substilis: A riview. African Journal of Agricultural Research, 9(16): 1265 - 1277.
Surtikanti. 2013. Cendawan Peronosclerospora sp. penyebab penyakit bulai di Jawa Timur. Balai Penelitian Tanaman Serealia. Maros

Wakman, W. 2004. Penyakit Bulai pada Tanaman Jagung, Tanaman Inang lain, Daerah Sebaran dan Pengendaliannya. Seminar Mingguan Balai Penelitian Tanaman Serealia Lain. Maros

Zainuddin., A.L.Abadi, dan L.Q. Aini.2014. Pengaruh pemberian Plant Growth Promoting Rhizobacteria (Bacillus subtilis dan Pseudomonas fluorescens) terhadap penyakit bulai pada tanaman jagung (Zea mays L.). Jurnal HPTUniversitas Brawijaya, 2(1): $11-18$. 